DOI : 10.24014/pib.v2il.12023

\title{
Pelecehan Seksual, Seksisme Dan Pendekatan Bystander
}

Putri Miftahul Jannah

Fakultas Psikologi Universitas Islam Negeri Sultan Syarif Kasim Riau

putri.jannah@uin-suska.ac.id

\begin{abstract}
Abstrak
Pelecehan seksual kini menjadi perhatian publik dalam beberapa dekade terakhir dan menjadi salah satu bentuk kekerasan seksual yang angka kejadiannya terus meningkat. Pelecehan seksual dapat memberikan dampak psikologis yang buruk khususnya pada perempuan. Sebab, pelaku pelecehan seksual diketahui banyak didominasi oleh laki-laki. Meskipun banyak terjadi, kasuskasus pelecehan seksual masih belum ditanggapi serius oleh masyarakat ataupun pihak yang berwenang. Sebab pelecehan seksual biasanya tidak meninggalkan bekas fisik pada korban. Untuk itu, perlu mengetahui akar masalahnya. Secara singkat, uraian ini bertujuan untuk menunjukkan upaya dalam memahami dan memperkuat bahwa seksisme merupakan satu akar masalah dari kekerasan/pelecehan seksual yang terjadi terhadap perempuan oleh laki-laki, serta melihat potensi peran bystander sebagai salah satu jalan untuk mencegah angka pelecehan seksual meningkat.
\end{abstract}

Kata kunci: Bystander; Pelecehan Seksual; Seksisme

\begin{abstract}
Sexual harassment has become a public concern in recent decades and is a form of sexual violence whose incidence continues to increase. Sexual harassment can have a devastating psychological impact, especially on women. This because we know men dominate many perpetrators of sexual harassment. Even though there are many cases, sexual harassment cases are still not taken seriously by the community or the authorities, because sexual harassment rarely leaves physical marks on the victim. It is necessary to know the root of the problem. In short, this description aims to understand and reinforce that sexism is one of the root problems of sexual violence/ harassment against women by men, and to see the potential role of the bystander to prevent the rate of sexual harassment from increasing.
\end{abstract}

Key words: Bystander; Sexism; Sexual Harassment

\section{Pendahuluan}

Kasus kekerasan seksual dijajakan hampir setiap hari di media di seluruh dunia, termasuk Indonesia. Menurut catatan tahunan Komnas Perempuan Indonesia tahun 2017, kekerasan di ranah komunitas mencapai angka 3.092 kasus (22\%), di mana kekerasan seksual menempati peringkat pertama sebanyak 2.290 kasus (74\%), diikuti kekerasan fisik 490 kasus (16\%). Data ini hanya dikumpulkan dari kasus - kasus yang telah 
dilaporkan saja, karena banyak korban yang tidak mampu dan merasa takut untuk melaporkan kekerasan yang terjadi pada diri mereka (KOMNAS Perempuan, 2016). Di antara kekerasan seksual, pelecehan seksual dan perkosaan menjadi salah satu kekerasan yang kerap terjadi.

Korban dari pelecehan seksual pada umumnya adalah perempuan, namun tidak tertutup kemungkinan laki-laki juga pernah mengalaminya. Begitu juga dengan pelaku. Tindakan pelecehan ini bisa terjadi di berbagai kesempatan dan dilakukan oleh siapa saja, umumnya oleh laki-laki. Meskipun banyak terjadi, kasus-kasus pelecehan seksual masih belum ditanggapi serius oleh masyarakat ataupun pihak yang berwenang. Sebab pelecehan seksual biasanya tidak meninggalkan bekas fisik pada korban. Salah satu kasus yang cukup mengejutkan adalah kasus pelecehan yang ada di lingkup pendidikan. Hal ini tentu menjadi coretan merah masyarakat di mana institusi pendidikan adalah yang diharapkan mengajarkan dan memberikan contoh didikan yang baik kepada masyarakat umum, namun malah terlibat kasus yang semestinya tidak terjadi. Contoh pelecehan yang pernah terjadi dan sempat terungkap media di lingkup institusi pendidikan adalah kasus pelecehan yang dilakukan oleh oknum dosen UIN Sunan Gunung Djati, Universitas Mataram dan UIN Malang (bbc.com, 2019; Media, 2020; Zuhra, 2019).

Maraknya kasus pelecehan seksual yang terjadi di lingkungan kampus tentu menjadi catatan tersendiri di daftar pekerjaan rumah yang harus diselesaikan oleh institusi terkait. Terlebih kasus-kasus itu biasanya hanya menjadi sorotan sementara dan kemudian hilang entah ke mana. Padahal, dampak yang diterima korban akibat pelecehan bisa menjadi serius. Bagi kalangan mahasiswa, korban bisa membatalkan perkuliahan, mengubah rencana akademis, atau bahkan berhenti kuliah (Artaria, 2012). Selain itu diketahui pula, bahwa korban dapat mengalami kondisi fisik dan emosi yang sangat buruk, dan memiliki tingkat produktivitas yang rendah (Shupe et al, 2002).

Komnas Perempuan mendefinisikan pelecehan seksual sebagai tindakan seksual lewat sentuhan fisik maupun non-fisik dengan sasaran organ seksual atau seksualitas korban. Ia termasuk menggunakan siulan, main mata, ucapan bernuansa seksual, mempertunjukan materi pornografi dan keinginan seksual, colekan atau sentuhan di bagian tubuh, gerakan atau isyarat yang bersifat seksual sehingga mengakibatkan rasa tidak nyaman, tersinggung, merasa direndahkan martabatnya, dan mungkin sampai menyebabkan masalah kesehatan dan keselamatan. Hal ini sejalan dengan Sbraga dan O'Donohue (2000), yang mengatakan bahwa pelecehan seksual dapat dideskripsikan sebagai perilaku yang memiliki rentang dari bahan bercandaan bernuansa seksis sampai tindakan perkosaan. Jadi dapat disimpulkan bahwa pelecehan seksual adalah tindakan fisik, verbal atau non-verbal yang menyasar pada seksualitas korban yang memiliki rentang tindakan dari bahan olokan bernuansa seksis sampai perkosaan.

Telah banyak penelitian yang menunjukkan adanya hubungan antara seksisme dan pelecehan seksual. Seksisme disebut-sebut sebagai salah satu akar masalah pelecehan 
seksual. Seksisme adalah sikap dan motif merendahkan perempuan, secara eksistensialmenyangkut tubuhnya, pemikirannya, perasaannya - yang dianggap sebagai inferior dan boleh diperolok atau dihina (Candraningrum, 2014). Seksisme terjadi dalam berbagai aspek, termasuk pelecehan seksual. Lebih lanjut Candraningrum (2014) menyatakan keberangkatan dari seksisme adalah stereotype atau pembekuan sifat dan peran perempuan pada perihal tertentu yang sesungguhnya merugikan eksistensinya. Pada mulanya seolah seksisme adalah hiburan ringan dan yang menjadi hiburan tak perlu jadi tersinggung karenanya. Tetapi kemudian ini membangun sebuah budaya yang "tak peduli" yang kemudian menjadi "tak sensitif" - minimnya sensitifitas ini kemudian melahirkan kekerasan pada dunia yang lebih kasat mata seperti eksploitasi seksual, kekerasan, perkosaan dan bahkan pembunuhan (Candraningrum, 2014).

Seksisme terhadap perempuan adalah dampak prasangka berdasarkan ketidaksetaraan kuasa sosial dan menyebabkan hal negatif terjadi seperti kekerasan berdasarkan gender -- pelecehan seksual misalnya -- (Kilmartin et al, 2014). Baik lakilaki ataupun perempuan, keduanya bisa saja menjadi aktor yang menginternalisasi seksisme. Mereka melegitimasi subordinasi perempuan dan superioritas laki-laki (Glick \& Fiske, 1996). Sejalan dengan hal itu, pelecehan seksual disebut terjadi karena adanya motif pelaku untuk mempertahankan status sosial dalam hirarki gender yang ada (superior dan subordanasi). Fakta bahwa status sosial distratifikasi oleh seks memotivasi dan membuat laki-laki mempertahankan status mereka berdasarkan seks dengan cara menghina status orang lain dalam konteks seksual (Berdahl, 2007). Motivasi untuk mempertahankan status ini lebih tampak pada laki-laki dibandingkan perempuan. Lakilaki yang mendukung dominansi laki-laki dan subordinasi perempuan mengatakan bahwa mereka akan mengeksploitasi perempuan secara seksual kapanpun mereka bisa (dan mereka benar-benar melakukannya) (Franke, dalam Berdhal, 2007). Secara sederhana, uraian ini kemudian menyimpulkan dan memperkuat bahwa seksisme merupakan satu akar masalah dari kekerasan/pelecehan seksual yang terjadi terhadap perempuan oleh laki-laki. Namun, pelecehan seksual, tidak hanya bisa dilihat dari pelaku dan korban saja. Terdapat peran bystander yang memiliki potensi untuk mencegahnya terjadi.

\section{Pembahasan}

\section{Pelecehan Seksual}

Komnas Perempuan mendefinisikan pelecehan seksual sebagai tindakan seksual lewat sentuhan fisik maupun non-fisik dengan sasaran organ seksual atau seksualitas korban. Ia termasuk menggunakan siulan, main mata, ucapan bernuansa seksual, mempertunjukan materi pornografi dan keinginan seksual, colekan atau sentuhan di bagian tubuh, gerakan atau isyarat yang bersifat seksual sehingga mengakibatkan rasa tidak nyaman, tersinggung, merasa direndahkan martabatnya, dan mungkin sampai 
menyebabkan masalah kesehatan dan keselamatan. Hal ini sejalan dengan Sbraga dan O'Donohue (2000), yang mengatakan bahwa pelecehan seksual dapat dideskripsikan sebagai perilaku yang memiliki rentang dari bahan bercandaan bernuansa seksis sampai tindakan perkosaan. Jadi dapat disimpulkan bahwa pelecehan seksual adalah tindakan fisik, verbal atau non verbal yang menyasar pada seksualitas korban yang memiliki rentang tindakan dari bahan olokan bernuansa seksis sampai perkosaan.

\section{Seksisme}

Seksisme merupakan pandangan dan perilaku yang bersumber pada kriteria gender, yang dapat menciptakan batasan perilaku kita terhadap spesifik gender (Thompson, 1995). Menurut Swim dan Hyers (2009) seksisme didefinisikan sebagai sikap, kepercayaan, dan perilaku individu, dan praktik organisasi, kelembagaan, dan budaya yang mencerminkan evaluasi negatif individu berdasarkan jenis kelamin atau mendukung status perempuan dan laki-laki yang tidak setara. Pada dasarnya, seksisme didasari oleh sikap, stereotipe dan praktek budaya yang mempromosikan keyakinan bahwa perempuan adalah kelompok yang kurang kompeten dan kurang memiliki kuasa dan status dibandingkan laki-laki (Swim \& Hyers, 2009). Seksisme itu sendiri terdiri dari manifestasi tingkah laku overt, covert dan subtle form. Seksisme overt adalah yang dapat dilihat dan diobservasi dalam bentuk ketidaksetearaan dan perilaku yang merugikan perempuan. Seksisme covert adalah termasuk didalamnya keterlibatan dalam ketidaksetaraan dan perlakuan merugikan terhadap perempuan secara tersembunyi. Seksisme subtle melibatkan stereotipe atau bias yang secara tidak sadar menghasilkan perlakuan ketidaksetaraan dan merugikan perempuan, yang tidak ditangani dan diperhatikan karena dianggap kebiasaan (Zawadki et al, 2013).

Sikap dan kepercayaan seksis tentang perempuan membantu menjustifikasi dan mempertahankan status laki-laki yang tinggi dan lebih powerful di kehidupan masyarakat dalam hal relasi gender (Berke \& Zeichner, 2016). Seksisme moderen menyebutkan terdapat dua dimensi seksisme yaitu hostile sexism (HS) dan benevolent sexism (BS), di mana keduanya membentuk integrasi sistem ideologi yang dikenal dengan ambivalent sexism. HS merepresentasikan ekspresi antipati terhadap perempuan, dan BS adalah sikap yang menempatkan perempuan dalam posisi yang "menyenangkan".

Pada dasarnya, terdapat beberapa domain dalam relasi gender menurut Glick dan Fiske (2001), yaitu:

a. Patriarki: Dominatif dan Protektif

Patriarki dan kuasa struktural laki-laki memiliki implikasi penting pada konten hostile dan benevolent seksisme. Konten hostile adalah dominative paternalism, yaitu keyakinan tentang laki-laki harusnya mempunyai kuasa yang lebih daripada perempuan dan perempuan takut untuk merebut kuasa laki-laki, dan protective paternalism, yaitu pandangan bahwa laki-laki seharusnya melindungi 
dan menjaga perempuan yang bergantung padanya. Sikap ini tercermin dalam perilaku sehari-hari seperti keyakinan bahwa seharusnya laki-laki-lah yang mengambil keputusan penting dalam kehidupan pernikahan, dan menjadi pelindung utama bagi keluarganya.

b. Perbedaan gender: Kompetitif dan komplementer

Manusia cenderung melakukan kategorisasi dalam hidupnya. Dalam hal ini kategorisasi dilakukan untuk membedakan identitas dan peran gender yakni lakilaki dan perempuan yang dikonstruksi oleh sosial. Perbedaan gender kompetitif menggarisbawahi keyakinan bahwa perempuan adalah kelompok yang inferior dari laki-laki sehingga perempuan tidak bisa berkompetisi untuk meraih status yang tinggi. Di samping itu, stereotipe perempuan tidak terjadi hanya dalam bentuk permusuhan/hostile akan tetapi juga dalam bentuk yang menyenangkan, di mana perempuan diharapkan memiliki sifat keramahan, mengasihi dan kehangatan. Oleh karena itu, dalam rumah tangga perempuan diharapkan bisa melengkapi dan kooperatif dengan laki-laki sehingga membuat laki-laki dapat berkonsentrasi dengan karirnya. Ketergantungan peran gender seperti itu secara subjektif merupakan bagian dari perbedaan gender komplementer, yang menekankan bahwa perempuan adalah gender yang lebih baik untuk menjadi komplementer tapi tetap memiliki status yang lebih rendah dibandingkan lakilaki.

Domain seksisme kemudian mempertahankan ketidaksetaraan gender di masyarakat melalui interaksi interpersonal yang menggiring pada penindasan perempuan. Pada beberapa penelitian disebutkan bahwa seksisme memiliki dampak yang cukup serius dalam keseharian perempuan. Pengalaman seksis berasosiasi dengan pengaruh negatif, lemahnya performa kognitif, dan perasaan inkompeten, merasa tidak nyaman, meninggikan level kemarahan dan depresi serta menurunkan self-esteem (Swim et al, 2001). Namun terkadang perempuan merasa sulit untuk mengidentifikasi pengalaman seksis yang terjadi di kehidupannya. Begitu juga dengan laki-laki. Ayres, Friedman, dan Leaper (2009) menyebutkan dalam keseharian, interaksi interpersonal yang memungkinkan sekali terjadi adalah cat calls dan komentar-komentar terkait seksualitas perempuan (yang merupakan salah satu bentuk pelecehan seksual/objektifikasi seksual). Komentar seksisme baik dalam bentuk hostile sexism (misalnya "pekerjaan berhitung tidak usah untuk dia, dia kan perempuan, performa perempuan dalam hal matematika tidak bagus", "perempuan semestinya manut sama laki-laki"), dan benevolent sexism (misalnya "biar saya saja yang bawa barang-barangnya, perempuan harusnya tidak bawa barang yang berat-berat", "pakai baju yang ketat saja, kamu terlihat seksi"), belum tentu dipersepsikan sama oleh setiap perempuan sebagai komentar seksis. Sebab, terkadang komentar seperti itu terjadi dalam situasi yang ambigu sehingga memungkinkan 
perempuan mengganggapnya sebagai pujian terutama komentar yang tergolong benevolent sexism (Ayres, Friedman \& Leaper, 2009).

Sibley, Wilson dan Duckit (2007) menyebutkan struktur sosial patriarki memperkuat kepercayaan bahwa laki-laki seharusnya memiliki kekuatan yang lebih besar dibandingkan perempuan dan bahwa perempuan harus dilindungi oleh laki-laki. Adanya "reinforce" untuk paham patriarki dan stereotipe peran gender (seksisme) dapat menimbulkan banyaknya masalah penindasan perempuan yang dilakukan oleh laki-laki (Thompson, 1995). Walau banyaknya laki-laki melakukan penindasan terhadap perempuan akibat dari adanya seksisme ini, bukan berarti laki-laki harus bertanggungjawab penuh atas adanya fenomena ini lahir. Sebab seksisme merupakan fenomena turun temurun yang bisa menguat atau menghilang bergantung pada "reinforce" yang dilakukan laki-laki dan perempuan terhadap fenomena ini.

\section{Pendekatan Bystander}

Fenomena pelecehan seksual sebenarnya tidak hanya terkait pada pelaku dan korban saja, akan tetapi juga terkait dengan saksi mata yang berada di sekitar lokasi kejadian (bystander). Mereka berpotensi untuk melakukan pencegahan, sebab sebenarnya memiliki peran untuk mengurangi kekerasan seksual. Banyard (2015) mendefinisikan bystander sebagai saksi terhadap perilaku negatif (keadaan darurat, kejahatan, pelanggaran peraturan) di mana kehadiran mereka memiliki kesempatan untuk memberikan bantuan, berkontribusi pada perilaku negatif atau mendorong perilaku itu dalam beberapa cara, atau hanya sebagai orang yang mengamati tanpa melakukan apaapa. Respon yang berbeda dari bystander akan memberikan peran yang berbeda pula dalam suatu situasi. Bystander yang melakukan aksi dalam sebuah kejadian disebut sebagai upstanders atau defenders. Mereka aktif untuk berperilaku pro sosial atau untuk mengeskalasi masalah. Hal ini dibuat agar dapat membedakan mana orang yang yang hanya stand by tidak melakukan apa-apa dan mana yang aktif (Banyard, 2015).

Dalam melakukan sebuah aksi, terdapat beberapa faktor individual yang dapat memengaruhi perilaku seseorang. Banyard (2011) menyebutkan beberapa variabel berkorelasi signifikan dengan perilaku menolong oleh bystander, di antaranya sikap, emotional arousal, dan gender. Banyard (2008) menemukan banyaknya pengetahuan tentang kekerasan seksual berkorelasi dengan meningkatnya keaktifan bystander untuk beraksi terhadap kejadian kekerasan seksual. Seorang bystander akan merasa perlu bertindak ketika ia merasa bertanggung jawab untuk melakukannya. Penerimaan akan mitos perkosaan (yang menyatakan bahwa yang terjadi adalah urusan pelaku-korban, dan menyalahkan korban) semakin menurunkan rasa tanggung jawab bystander.

Selanjutnya, emosi memengaruhi kecenderungan seseorang untuk menolong (Baron, Branscombe, \& Byrne, 2006). Sebelum seorang bystander dapat memutuskan 
melangkah untuk menolong, ia perlu mengidentifikasi serta mengobservasi perilaku yang terjadi selama kejadian kekerasan seksual. Ia perlu mendefinisikan kondisi tersebut sebagai darurat. Banyard (2011) menyatakan bahwa arousal adalah kunci untuk menginterpretasikan situasi darurat atau tidak, dan dengan menolong seseorang dapat menurunkan tingkat arousal-nya. Dalam situasi kekerasan seksual, bystander berpotensi merasakan ketidaknyamanan psikologis ketika melihat korban. Banyard (2011) menyebutkan arousal dan emosi merupakan kunci untuk rasa bertanggung jawab yang mana rasa itu adalah bagian utama dari proses intervensi dalam kejadian kekerasan seksual. Selain itu, bila dilihat dari aspek gender, diketahui bahwa perempuan lebih membantu dibandingkan laki-laki dalam intervensi kejadian kekerasan seksual (Banyard, 2008). Hal ini dikarenakan perempuan memiliki perhatian tersendiri dan lebih banyak mengetahui tentang isu perempuan sebagai kelompok yang rentan akan kekerasan. Di samping itu semua, kepercayaan bahwa memiliki kemampuan untuk mengintervensi dan menolong perlu juga diperhitungkan dalam diri seseorang. Semakin tinggi tingkat kepercayaan maka semakin besar pula keinginan untuk menolong dalam situasi kekerasan seksual (Banyard, 2011).

Sementara itu, dalam konteks hubungan teman sebaya dan komunitas, bystander tidak hanya bisa berperan untuk menolong korban. Akan tetapi juga "menolong" pelaku untuk merancang dan melaksanakan perkosaan/kekerasan seksual lainnya seperti yang terjadi pada kasus remaja di Palu (Detik.com, 2014). Hal ini menunjukkan kehadiran bystander malah mengeskalasi masalah. Bijleveld, dkk. (2007) menyebutkan ada proses sosial yang terjadi pada kejadian kekerasan seksual khususnya perkosaan yang dilakukan oleh pelaku sebagai peer group.

Ketika bekerja sebagai kelompok, pelaku terlihat memiliki tujuan bersama, saling membantu melakukan perkosaan, misalnya, dengan membantu menjatuhkan atau merebahkan korban. Kepemimpinan kelompok dapat ditentukan oleh individu- individu yang terlibat dalam tahapan perkosaan termasuk pendekatan dan atau pembuangan korban. Ketika bekerja sebagai individual, kejadian perkosaan biasanya berlangsung kacau karena tiap anggota menggunakan cara dan mendahulukan keinginan masingmasing. Setelah kejadian, beberapa anggota kelompok biasanya meminta atau mengancam korban untuk tidak melaporkan perkosaan sementara yang lainnya menyusun cerita untuk dijadikan alibi (Bijleveld dkk, 2007)

Bentuk hubungan teman sebaya bisa dilihat juga dari sisi korban. Ketika norma komunitas dan teman sebaya sebagai bystander menyatakan bahwa kekerasan seksual tidak dilihat sebagai sebuah tindakan yang salah, maka sulit bagi bystander untuk bertindak menolong (Banyard, 2015). Oleh karena itu, bystander sebagai agen perubahan yang potensial, perlu membantu menciptakan norma dan peran yang tepat terkait kekerasan seksual, sehingga nantinya dapat mengurangi angka pelecehan/kekerasan seksual yang ada. 


\section{Kesimpulan}

Pelecehan seksual dapat dikatakan sebagai bentuk kekerasan seksual berbasis gender. Salah satu akar masalahnya adalah seksisme. Reduksi seksisme di kehidupan tentunya menjadi pekerjaan rumah bagi seluruh lapisan masyarakat. Banyaknya masalah yang muncul akibat seksisme seperti pelecehan terhadap perempuan sudah selayaknya menjadi perhatian bersama. Memanfaatkan potensi bystander dapat menjadi jalan untuk mencegah meningkatnya angka kejadian pelecehan seksual.

\section{Referensi}

Artaria, M. (2012). Efek Pelecehan Seksual di Lingkungan Kampus: Studi Preliminer. Biokultur, 1(1).

Ayres, M., Friedman, C., \& Leaper, C. (2009). Individual and Situational Factors Related to Young Women's Likelihood of Confronting Sexism in Their Everyday Lives. Sex Roles, 61(7-8), 449-460. http://dx.doi.org/10.1007/s11199-009-9635-3

Banyard, V. (2008). Measurement and Correlates of Prosocial Bystander Behavior: The Case of Interpersonal Violence. Violence And Victims, 23(1), 83-97. http://dx.doi.org/10.1891/0886-6708.23.1.83

Banyard, V. (2011). Who will help prevent sexual violence: Creating an ecological model of bystander intervention. Psychology Of Violence, 1(3), 216-229. http://dx.doi.org/10.1037/a0023739

Banyard, V. (2015). The Promise of a Bystander Approach to Violence Prevention. Springer Briefs In Criminology. http://dx.doi.org/DOI 10.1007/978-3- 31923171-6_2

Banyard, V., Moynihan, M., \& Plante, E. (2007). Sexual violence prevention through bystander education: An experimental evaluation. Journal Of Community Psychology, 35(4), 463-481. http://dx.doi.org/10.1002/jcop.20159

Baron, R., Branscombe, N., \& Byrne, D. (2006). Social Psychology (11th ed.). Boston: Allyn Bacon.

Berdahl, J. (2007). Harassment based on sex: Protecting social status in the context of gender history. Academy of Management Review, 32(2), 641-658.

Berke, D., \& Zeichner, A. (2016). Testing a Dual Process Model of Gender-Based Violence: A Laboratory Examination. Violence And Victims, 31(2), 200-214. http://dx.doi.org/10.1891/0886-6708.vv-d-14-00060

Bijleveld, C., Weerman, F., Looije, D., \& Hendriks, J. (2007). Group Sex Offending by Juveniles: Coercive Sex as a Group Activity. European Journal Of Criminology, 4(1), 5-31. http://dx.doi.org/10.1177/1477370807071728 
Candraningrum, D. (2014). Seksisme, Pink Collar Ghetto, dan Brand-Building dalam Media. Jurnal Perempuan. Retrieved 3 June 2017, from http://www.jurnalperempuan.org/blog/seksisme-pink-collar-ghetto-dan-brandbuilding-dalam-media

Dugaan pelecehan seksual di kampus: Kesaksian 'Zahra' dan 'Sandra', dua mahasiswi di Bandung - BBC News Indonesia. BBC News Indonesia. (2019). Retrieved 21 January 2021, from https://www.bbc.com/indonesia/indonesia-47314777.

Glick, P., \& Fiske, S. T. (1996). The ambivalent sexism inventory: Differentiating hostile and benevolent sexism. Journal of Personality and Social Psychology, 70, 491512.

Glick, P., \& Fiske, S. (2001). Ambivalent Sexism. Advance In Experimental Social Psychology, 33. http://dx.doi.org/10.1037//0003-066x.56.2.109

Ini Pengakuan Siswa SMA Pelaku Pemerkosaan Adik Kelas ke Polisi. (2014). detiknews. Retrieved 30 May 2017, from https://news.detik.com/berita/2775622/inipengakuan-siswa-sma-pelaku-pemerkosaan-adik-kelas-ke-polisi

Kilmartin, C., Semelsberger, R., Dye, S., Boggs, E., \& Kolar, D. (2014). A Behavior Intervention to Reduce Sexism in College Men. Gender Issues, 32(2), 97-110. http://dx.doi.org/10.1007/s12147-014-9130-1

Komisi Nasional Anti Kekerasan terhadap Perempuan. (2017). Catatan Tahunan. Jakarta. Retrieved from http://www.komnasperempuan.go.id/wpcontent/uploads/2017/04/CATAHU-2017-Komnas-Perempuan.pdf

Komisi Nasional Anti Kekerasan terhadap Perempuan. (2016). Catatan Tahunan tentang Kekerasan terhadap Perempuan 2016. Jakarta : KOMNAS Perempuan.

Media, K. (2020). Kasus Pelecehan Seksual Oknum Dosen: Korban Sulit Melapor Takut Identitas Tersebar Halaman all - Kompas.com. KOMPAS.com. Retrieved 21 January 2021 , from https://regional.kompas.com/read/2020/07/24/11083451/kasus-pelecehanseksual-oknum-dosen-korban-sulit-melapor-takut-identitas?page=all.

Sbraga, T., \& O'Donohue, W. (2000). Sexual Harassment. Annual Review Of Sex Research, 11, 258.

Sibley, C. G., Wilson, M. S., \& Duckitt, J. (2007). Antecedents of men's hostile and benevolent sexism: The dual roles of social dominance orientation and right-wing authoritarianism. Personality and Social Psychology Bulletin, 33(2), 160-172.

Shupe, E., Cortina, L., Ramos, A., Fitzgerald, L., \& Salisbury, J. (2002). The Incidence and Outcomes of Sexual Harassment Among Hispanic and Non-Hispanic White Women: A Comparison Across Levels of Cultural Affiliation. Psychology of 
Women Quarterly, 26(4), 298-308. http://dx.doi.org/10.1111/1471-6402.t01-200069

Swim, J. K., \& Hyers, L. L. (2009). Sexism. In T. D. Nelson (Ed.), Handbook of prejudice, stereotyping and discrimination (pp. 407-430). New York, NY: Psychology Press.

Thompson, N. (1995). Men and anti-sexism. British Journal Of Social Work. Retrieved from http://bjsw.oxfordjournals.org/content/25/4/459.short

Zawadzki, M., Shields, S., Danube, C., \& Swim, J. (2013). Reducing the Endorsement of Sexism Using Experiential Learning. Psychology Of Women Quarterly, 38(1), 7592. http://dx.doi.org/10.1177/0361684313498573

Zuhra, W. (2019). Dosen Predator yang Masih Berkeliaran di UIN Malang - Tirto.ID. tirto.id. Retrieved 21 January 2021, from https://tirto.id/dosen-predator-yangmasih-berkeliaran-di-uin-malang-dK4i. 